\title{
CLOUD-BASED COMPUTING: PROVIDING AN ADVANTAGE TO A SMALL NEW ZEALAND WINE BUSINESS 1
}

\author{
Sharon L. Forbes and Khalid Alsulaiman, Lincoln University, New Zealand
}

$\mathrm{I}$

n late 2018 the owners of Wooldale Estate (Wooldale) decided it was time to review the effectiveness and utility of the cloud-based software programs that their company had adopted three years earlier. In particular, the owners needed to know if the post implementation and usage of the cloud-based software programs were providing sufficient customer relationship management (CRM) data. Wooldale was a small, family-owned, wine company situated in the South Island of New Zealand. It comprised a vineyard, a restaurant, and an event venue at a location approximately 30 minutes from an urban area. The owners, Oliver and Charlotte Martin, had purchased the property in 2002 and sought to position their company as a customer-focused, wine-celebration business.

Through its positioning as a wine-celebration business, Wooldale was able to sell 95 percent of its wines directly to customers. Wooldale primarily sold its wines through the restaurant and cellar door at events, such as weddings, conferences, or corporate functions and when hosting cruise ship passengers. Customers were also able to purchase wine directly from Wooldale through the company's website, Facebook page, or via email. A very small portion of their total wine sales was made through small, local, specialty stores, including florists and cafes.

Oliver Martin performed a managing director role within the company, overseeing the entire business with a specific focus on marketing. Charlotte Martin managed the restaurant, the events side of the business, and human resources (HR). Permanent staff, including a chef, waiters, and a part-time vineyard manager, were also employed by the company. Additional contract labor was

\footnotetext{
1 While this case study was based on a real company located in the South Island of New Zealand, the names of the company and of the individuals involved were disguised at their request.
}

The authors wish to acknowledge the efforts of former colleague, Rebecca Kennedy, in developing the interview questions and collecting the data that has been used to write this case study.

C)2019 Sharon L. Forbes and Khalid Alsulaiman 
hired for busy periods in the vineyard or for helping at large events. Winemaking and bottling functions were outsourced to a local winery.

Oliver wondered aloud:

To what extent were we enjoying any advantages from cloud-based software programs? Because I was working at more than one job, I needed the reach that CRM was able to give me; I needed to communicate with people on a regular basis. Even though I was the managing director of this business, I was also doing maintenance, mowing the lawns, as well as the recycling.

Considering their time commitments outside the business, the Martins questioned if cloud-based solutions would enable them to spend less of their time, effort, and money to manage and sustain their small wine business.

\section{EARLY CHALLENGES}

In the early years after Wooldale was established, the Martins faced three key hurdles.

The first hurdle was the lack of time. As both Oliver and Charlotte had full-time jobs outside Wooldale, the time that they were able to devote to this new business was limited. They started the company as a lifestyle business. As Oliver reflected, "We did this for fun...we didn't have [extra] time, so we needed to balance time versus rewards." Thus, maximizing profits was not the overarching reason why they started the business. Profitability, as a goal, was important to keep the business going, but it was also balanced against other non-monetary goals, such as the pleasure they would receive from running a wine business and the development and refinement of their entrepreneurial skills.

The second hurdle was the cost of managing Wooldale's finances, especially accounting. Given the small size of their new business, the Martins wanted a more hands-on experience in managing every aspect of the company, including accounting. Neither Oliver nor Charlotte possessed a strong skill set in accounting, so they had outsourced Wooldale's accounting activities to an external accountant. Periodically, the accountant would drive to Wooldale to meet with the Martins to make sure that the business records and transactions were kept appropriately. The Martins observed that conventional accounting had constrained their ability to exert more control over their business and minimized their capability to acquire more knowledge about their customers. Having an external accountant had also proven to be an inflexible and costly way of managing the business's finances.

The third hurdle was the difficulty of reaching a wider target customer market. When the company was first established, Oliver and Charlotte managed customer relationships by keeping a simple list in an Excel spreadsheet. Under this arrangement, they could send direct email messages via Outlook to a maximum limit of 150 email addresses that they copied from the spreadsheet. With a customer base of about 4,000, this meant that a group of 150 email addresses 
needed to be copied from Excel roughly 26 times. As a consequence, Oliver and Charlotte were unable to practically and efficiently send messages or offers out to a large number of customers.

\section{CLOUD-BASED BUSINESS TOOLS}

Nevertheless, the difficulties that the business encountered in the early years began to diminish when the managers at Wooldale started adopting cloud-based software programs to help run the business. These were software packages or applications that the user did not have to install on their hardware on their premises. Instead, the software could be accessed and used via the internet using a web browser. For a monthly or yearly payment, the software vendor gave the user online access to the software, which was why such applications were sometimes described as web-based applications. The software that was being provided as a service was actually installed on the vendor's servers, and the user's computer connected to that server via the internet. Thus, the vendor was in full control of the software's capabilities, updates, and maintenance. This information technology (IT) arrangement was known as Software as a Service (SaaS), and it represented only one form of cloud computing. Other forms of cloud computing included Infrastructure as a Service (IaaS) and Platform as a Service (PaaS). For further information about the three cloud-based tools used by Wooldale, see Table 1 in the Appendix.

In 2007 Xero, an accounting software, was introduced into the market. A few years afterward, Wooldale started using Xero to run the business's accounting activities. Although the customers' database within Wooldale was technically stored in the cloud, Xero enabled the managers to confidently perform the business accounting activities themselves, despite not being experienced or trained in accounting. This was due to the simplicity and user-friendliness of the Xero program. By creating an account in Xero, the managers of Wooldale were able to conveniently perform a number of accounting activities. For example, they could easily generate charts to analyze the total amount of cash going in and out of the business; they could reconcile transactions; and, they could analyze at a glance the accounts payable and receivable. All these features were conducted conveniently from an application on a handheld device. This gave the managers more control over their business. According to Oliver, "With Xero, you can be worldly about your business without understanding a lot of accounting."

Furthermore, the implementation of Xero reduced the business expenditure on accounting services. After adopting Xero, the Martins were able to take over the detailed bookkeeping and relegate the external accountant to an advisor. Within this new role, the external accountant had online access to Xero account and was able to monitor the business books in real time and intervene if there were any data entry or coding errors. Moreover, because of that online access, there was less need for regular face-to-face meetings between the managers and the accountant. All the costs associated with those meetings were cut, including the one-hour travel time. After adopting Xero, Oliver reflected, "Accounting was happening every day." He further explained: 
I was getting more value because of it. I was able to run a profit and loss statement today. I was able to change the ledger. I loved sending invoices. I sent statements as regularly as I possibly was able to. And, our accounting fees had actually gone down.

The company's successful experience with Xero encouraged the managers to adopt two more cloud-based applications: Capsule and ActiveCampaign. The decision to use Capsule as Wooldale's CRM software was made approximately two years after the company started using Xero. While Xero provided Oliver and Charlotte with a tool to manage the financial side of the business, Capsule allowed them to manage customer relationships. The decision to use Capsule, as opposed to one of the many other available CRM tools, was based on its ability to seamlessly integrate with Xero. Alongside Capsule, the company also began to use ActiveCampaign as a tool to manage all of their email communications. This application also integrated with Xero and Capsule.

Seamless integration occurred when the connection between stand-alone cloud-based applications was automated. Such integration enabled these applications to operate smoothly in synchronization as if they were built originally as components of one system or one application. Seamless integration between different software applications was akin to the coordination between different departments inside one organization in terms of how they standardize, store, and process data. Each application was expected to carry out a different business activity, such as accounting, CRM, or email marketing; however, data entry and updating was automated across these applications because they had integration capabilities. This reduced the duplication and loss of data and increased efficiency.

Customer relationship management software, particularly the Capsule application, was important to Wooldale, as it enabled the company to reach a large number of customers practically and efficiently. After implementing the Capsule and ActiveCampaign tools, the business was able to quickly and easily communicate with more than 4,000 customers at once. These tools facilitated a channel of communication between the business and its customers that was rich in content, frequent, and efficient.

When asked what CRM meant to him and to the Wooldale company, Oliver replied, "CRM was about gathering names. It was about a way to create customer data that was enduring, that you were able to reuse for as many aspects of your business as possible." Upon adopting the Capsule software, CRM was viewed by Oliver and Charlotte as the principal business process in the company, as it drove everything they did. "Using these tools, I was able to deliver content that was richer than a NZ\$500 ad and content that customers were able to make [immediate] decisions on," said Oliver.

One important element of the CRM software was its ability to easily create detailed customer profiles. For example, a customer's profile could contain different pieces of data, such as name, date of birth, customer type (i.e. business or individual), number of employees, purchase history, and their role (i.e. buyer, influencer, or advisor). However, to optimize the benefits from CRM software, a business had to continually collect customer data. As observed by Oliver, "This was the case with CRM. You had to feed the engine. So, you had to get the data as the fuel." This 
thinking was reflected in how the company collected customer data. For example, a form was attached to the menu of the Wooldale restaurant, which customers could fill in to join the company's mailing list. Customers could also subscribe to this mailing list by simply scanning the company's quick response $(\mathrm{QR})$ code using their mobile phones. Additionally, links to the company's email system were displayed prominently on the company's website and Facebook page. Moreover, the wait staff were encouraged to let customers know about the mailing list and how they could subscribe to it. With effective database management, the Capsule software could be conveniently used to improve the quality of the customer data because it made it easy for the user to identify any incomplete customer profiles. Oliver reflected,

It was not just the functions of the CRM software; it was also improving the data. I might want to send an email to a customer who was in my database to ask when her birthday was, so I would able to send her a birthday offer.

The CRM software was an important part of Wooldale's customer segmentation process as well. The business used the software to segment customers based on what they purchased. These categories included: wine purchaser (through cellar door, online, or at a wine show), restaurant customer, celebration customer, and conference customer. Celebration customers were further divided into different sub-categories, such as weddings and Christmas parties. Segments were recorded in the CRM system as tags, and each customer profile could have one or multiple tags attached to them.

Additionally, the CRM software allowed the Martins to further segment their customers based on the stage of their purchasing decision. Categories for this segmentation included suspect, booked, and held-the-event. The suspect tag referred to prospective customers who had shown some previous interest in Wooldale, but had yet to make a purchase (for instance, they may have sent an email inquiry). The booked tag referred to customers who had placed an order for wine or those who had made a restaurant or event booking. The held-the-event tag referred to customers who had done business with Wooldale in the past.

Moreover, lead scoring was another form of segmentation that was available to Wooldale through their email marketing software. Lead scoring segmented customers based on their interaction with the business offerings and messages. A customer earned points every time they opened an email from Wooldale, clicked through to the company website, or downloaded information. The more points the customer earned, the more marketing messages and personalized offers they would receive from the business.

Additionally, the CRM software was particularly important for targeting the best potential customers for Christmas events. This was due to two factors. Firstly, the period in which Christmas events could be held was rather short (i.e. late November and first weeks in December). Secondly, Wooldale earned a large portion of its revenue from Christmas bookings. Therefore, it was important to target the most profitable customers for Christmas events. For this purpose, the business relied on the CRM software to communicate with the preferred customer segments early in the year. The business managers sent out messages to both previous and prospective customers to promote the Wooldale venue and to invite customers to make a 
Christmas booking. The preferred customers were big companies with large budgets whose payment for the booking was likely to be made by the company as opposed to a staff social fund. This targeting strategy increased the likelihood of securing 100-seat bookings, which was the maximum capacity of the venue, during the short period available for these Christmas events.

Many of Wooldale's CRM activities in terms of segmenting and targeting were set automatically based on customers' actions and the frequency and recency of those actions. Thanks to Capsule and ActiveCampaign, the managers were able to set up, on a regular basis and throughout the year, automated personalized marketing offers that were sent to particular customers who had high lead scores. Such automated messages reduced time and effort by the owners and kept the customer attached to the business. For example, Oliver sent an email message in April 2015 to a Wooldale customer named Rebecca. His offer to Rebecca was based on a previous purchase decision that she had made:

Dear Rebecca,

Thank you for ordering the Wooldale Estate 2013 Riesling. Now, the 2015 is coming up. Because you are a valued customer and you have purchased before, I want to place an offer in front of you that says you are going to be one of the first to have it. It will be available to you in August.

Oliver further commented: "So, CRM should not be about selling something necessarily that day; it should be about building the customer experience."

Furthermore, customers who had made a wedding inquiry in the previous 30 days automatically received a message from Wooldale every seven days. These messages were triggered when customers clicked on any links included in previous messages or on specific pages on the company's website. Automation was also used in managing the company's relationship with customers who were tagged as booked. Because events at the Wooldale were reserved months in advance, those in the booked segment automatically received a monthly newsletter, which Oliver believed kept his customers "fresh and happy." He elaborated:

We had done a deal with a bus company to get a bus from the city to Wooldale Estate for four bucks per customer. I wanted to send that offer to these customers two or three times before their event. Why? If I got them out here on a bus, it meant none of them were driving. They would enjoy beverages here and get home safely.

The importance of the CRM software also stemmed from its ability to gauge the value of the business's various marketing activities. The software could be used to track where and how the customer's details entered the system. For example, the system might indicate that the customer's name and address were obtained at a wine show. Such information would guide subsequent marketing decisions in terms of whether it was beneficial for the company to attend a particular wine show.

In addition to the different functions outlined above, the Capsule software had other features that were, to some extent, useful in managing the business's relationship with its customers. For instance, the managers could use the software to create CRM projects, known as "cases." An 
example of a CRM case would be a local A\&P show, which was an annual show where livestock, food, wine, and entertainment were showcased. A CRM case about this show would include all the communications that the business had with customers regarding that show. Other useful features of the software included the user's ability to write unstructured notes about customers and to conduct a keyword search.

An important benefit that Wooldale gained from using the CRM software was efficiency in both time and costs. The business paid only NZ\$12 per month for using Capsule and NZ\$40 per month for ActiveCampaign. Compared to the critical role that these tools played in the management of the business and the advantage of integration between accounting and CRM software, the costs were very low. In addition, these cloud-based tools could be accessed by the managers at any time and from anywhere using the free application on their mobile phones. In his marketing role, Oliver accessed Capsule in his free time, during which he would spend approximately 20-30 minutes updating data or communicating with customers. Because the business was a small company, only Oliver and Charlotte had access to and used the Capsule software. Other staff were not required to use it. Wooldale used the CRM software to communicate with previous and potential customers. Having the means to send targeted messages or offers to specific, tagged customers allowed the company to reduce their investment in advertising through traditional media. In fact, advertising costs accounted for only two percent of the business's total revenue.

In addition to cost efficiency, the Capsule software allowed for the progressive and flexible adoption of the software. Rather than paying for a whole lot of functions and features, some of which might not be needed, the managers could pick specific functions that could be integrated over time into the CRM and accounting systems. An example of a tool that the managers wanted to integrate into the system was an online chat capability. Such a tool would provide an instant communication channel with customers and it would link back to the business's CRM database. The managers of the company would be able to install and uninstall such add-on functions and features easily and at a minimal cost.

While cloud-based applications had significantly benefitted Wooldale, the implementation of these tools was not without challenges and disadvantages. Such challenges and disadvantages seem to have stemmed from those adopted applications themselves, the size of the company, and the niche segment within the wine sector that the company focused on. While integration between applications was one of the factors that attracted Oliver to use Xero, Capsule, and ActiveCampaign, the ability to integrate these applications was limited in certain instances. For example, while Capsule could access certain financial information from Xero, such as individual invoices and whether an invoice had or had not been paid, it could not access overdue payments alerts in Xero.

Moreover, the small size of the company rendered the optimal utilization of all the software features unnecessary. Capsule's cases, for example, were used minimally in the management of Wooldale's customer relationships because the business's CRM software was used by only Oliver and Charlotte. Had the software been used by a larger group of people, working at times 
distantly from each other, Capsule's cases would have been of significant help in maintaining a good level of coordination between them. Oliver reflected upon the contrasts between the CRM software implementation at Wooldale and the CRM implementation at a high-tech consultancy company, of which he was simultaneously the marketing director. Oliver was of the opinion that in a larger-sized company like Wooldale:

You needed everybody on the team using CRM. If one of your staff was not using the CRM application to its potential, other staff members were not able to know where that staff member was at. They were not able to see that member's order book coming through, and the whole CRM implementation became a bit lopsided.

Furthermore, Wooldale's implementation of its cloud-based CRM software was slightly regulated by the way the company had positioned itself in the New Zealand wine sector as a wine-celebration business. The bulk of the company's sales came from celebration events such as weddings and Christmas parties. Nevertheless, "These celebrations did not come across every week or every month. They were booked six months or a year out," Oliver said. Consequently, the company could not make customers who booked those events spend any more money ahead of that time. The company's use of its CRM tool was more frequent for customers who bought wine from Wooldale online. However, these customers represented the minority of the company's customer base. This was a clear contrast with how frequently customer relationships were managed at Oliver's other high-tech company where the need for CRM arose on a monthly basis.

\section{THE OWNERS' EVALUATION}

Because they still were working in their regular jobs, the Martins felt they lacked the time and skills necessary to run Wooldale. From their evaluation of the cloud-based solutions they had adopted, the Martins found that these tools were an efficient and effective way to acquire more control over their business, and that these tools would help them overcome some of the challenges their business would likely face in the future. 


\section{References}

Anon., (2013). Research findings from a national survey of New Zealand businesses: An exploration of business experiences with information and communication technology and purchasing services from other businesses. Wellington, NZ: Colmar Brunton.

Masset, B., \& Sekkat, I. (2011). Customer relationship management for SMEs in the cloud: A multiple case study analysis (dissertation).

Anon., (2013, July). Start-Up Special Report. Retrieved from https://www.myob.com/content/dam/myobredesign/nz/docs/MYOB Start-up Special Report_interactive.pdf

Anon., (2014, February). The voice of NZ business owners and managers. Retrieved from https://www.myob.com/content/dam/myob-redesign/nz/docs/MYOB NZ BUSINESS MONITOR NATIONAL REPORT 2014-1.pdf

Anon., (2015, August). The voice of NZ business owners and managers. Retrieved from https://www.myob.com/content/dam/myobredesign/nz/docs/MYOB_NZ_BUSINESS_MONITOR_August_2015.pdf

Zucca, G. (2010). "Direct-to-consumer sales in small wineries: A case study of tasting room and wine club sales." Proceedings of the 5th International Conference of the Academy of Wine Business Research, 8-10 February, Auckland, New Zealand. 


\section{APPENDIX}

Table 1

\section{Cloud-Based Business Tools Used by Wooldale Estate}

\begin{tabular}{|l|c|c|c|}
\hline Software & Xero & Capsule & ActiveCampaign \\
\hline Industry & $\begin{array}{c}\text { Software as a Service } \\
\text { (SaaS) }\end{array}$ & $\begin{array}{c}\text { Software as a Service } \\
\text { (SaaS) }\end{array}$ & $\begin{array}{c}\text { Software as a } \\
\text { Service (SaaS) }\end{array}$ \\
\hline Ypecialty & Accounting & $\begin{array}{c}\text { Customer relationship } \\
\text { management (CRM) }\end{array}$ & Email marketing \\
\hline Headquarters & 2006 & 2009 & 2003 \\
\hline Number of customers & Over 1.5 million & Over 10,000 & Over 50,000 \\
\hline $\begin{array}{l}\text { Number of add-ons } \\
\text { (integrations) }\end{array}$ & Over 600 apps & $\begin{array}{c}\text { Manchester, } \\
\text { United Kingdom }\end{array}$ & $\begin{array}{c}\text { United States } \\
\text { New Zealand }\end{array}$ \\
\hline Website & xero.com/nz & Illinois, & Opper 250 apps \\
\hline
\end{tabular}

Source: Company records. 